\title{
KARRIEREKVELD I LEGENES HUS
}

Tirsdag 21. januar 2014 ble det arrangert karrierekveld for leger i regi av Legejobber - Tidsskriftets stillingsportal. Over 100 deltakere lot seg inspirere av foredrag om etablering av egen praksis, internasjonalt arbeid og hvordan kombinere klinisk arbeid med forskning.

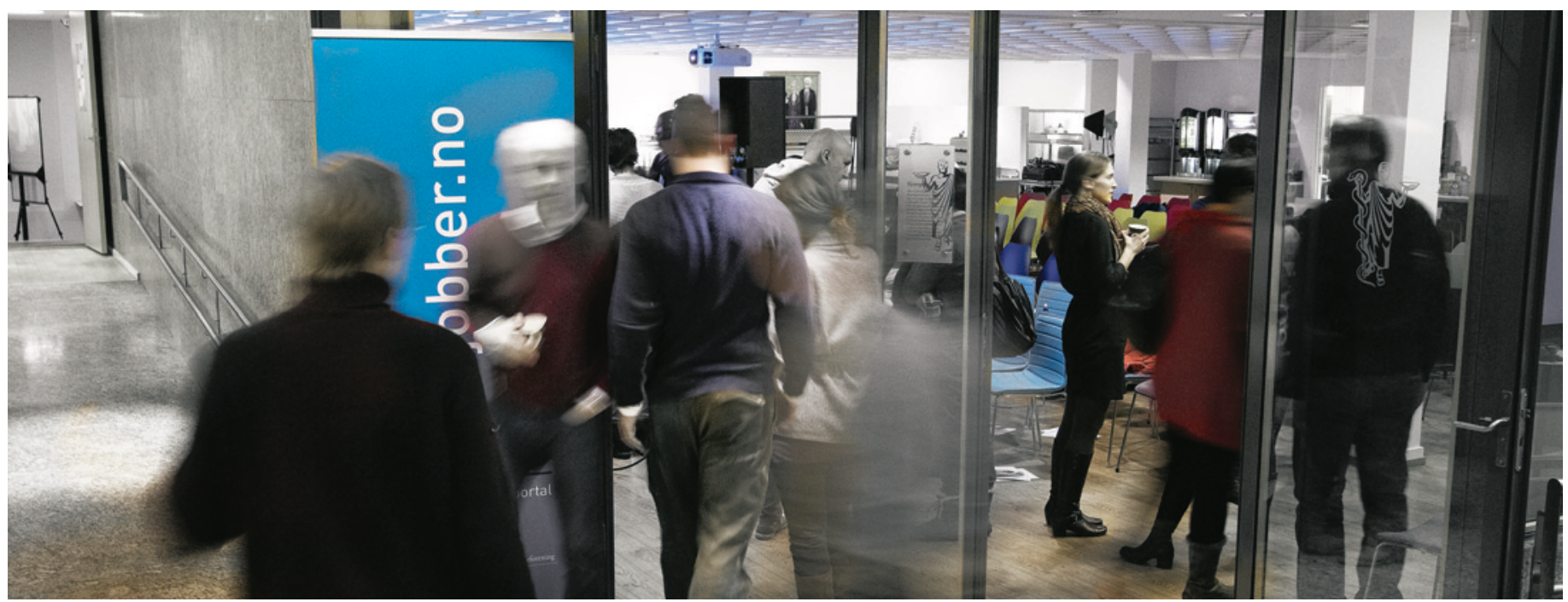

Den første karrierekvelden var preget av solid oppmøte og stort engasjement. Foto: Einar Nilsen

Kvelden ble åpnet av Tidsskriftets sjefredaktør, Charlotte Haug, som ønsket velkommen til den første karrierekvelden i regi av Legejobber.

\section{Karrierekvelder i flere byer}

Fellesnevneren for de besøkende var å få et innsyn i de karrieremulighetene som finnes for leger. Engasjementet var stort, og det var mange spørsmål i etterkant av foredragene. Legejobber, Tidsskriftets stillingsportal, ser svært positivt på oppmøtet og interessen for arrangementet, og ser frem til å holde tilsvarende karrierekvelder $\mathrm{i}$ andre deler av landet.

Tre foredrag ble holdt, og først ut var Anne Kjersti Befring, direktør i Avdeling for jus og arbeidsliv i Legeforeningen.

\section{Hvordan etablere egen praksis}

- Det finnes knapt grenser for hva leger kan brukes til, sa Befring. - Legeforeningens juridiske avdeling er daglig i kontakt med leger, og mange av dem har spørsmål angående egen praksis. Som fastlege er man næringsdrivende, og som næringsdrivende er det mye man skal holde orden på.

Befring fortalte at Legeforeningen kan bistå med etablering av praksis, både fastlegepraksis og privat praksis. Seminarets deltakere hadde rikelig med spørsmål.

\section{Internasjonalt arbeid}

Morten Rostrup var i 1996 med på å starte den norske avdelingen av Leger Uten
Grenser. Rostrup har jobbet i Zaire (nå Kongo), Angola, Irak, Haiti, Syria og en rekke andre land. Foredraget inneholdt mange historier fra landene han har jobbet $i$.

- Barn som går fra å være så underernærte at de ikke har mimikk i ansiktet og er helt apatiske, til en dag å smile: Det er det som holder oss oppe. Å jobbe ute, få kontakt med kolleger, holde kontakten i ettertid, det beriker, fortalte han.

\section{Hvordan kombinere klinisk arbeid med forskning}

- Hvorfor forske når man er lege? spurte Annetine Staff, professor og overlege ved Kvinneklinikken, Universitetssykehuset i Oslo. Svarene hadde hun klare.

- Fordi det er gøy, faglig utfordrende og globale karrieremuligheter, i tillegg er det til nytte for pasienter og samfunn, sa hun. Men hvordan skal man komme i gang?

Som medisinstudent har man muligheter gjennom forskerlinje og profesjonsoppgave. Etter ferdige medisinstudier vil det være viktig å få finansiering på plass. Staff fremhevet viktigheten av å kunne være en del av et miljø, med prosjekter som man kan ta del i. Hun har også vært med på å utvikle en forskningshåndbok med mange gode tips.

\section{Magnus Torgersen}

Tidsskriftet

\section{«Det finnes knapt grenser for hva leger kan brukes til» \\ Anne Kjersti Befring, Legeforeningen}

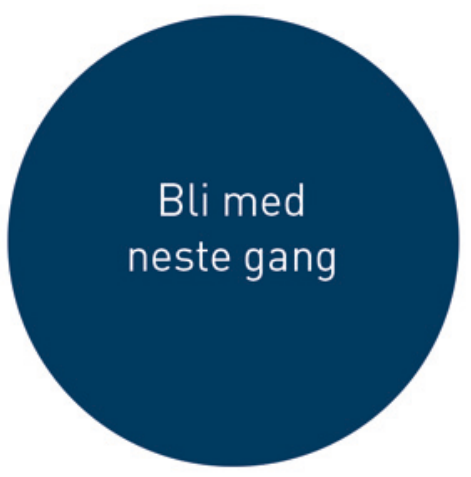

